\title{
CUSTOMER SATISFACTION AND CUSTOMER LOYALTY IN VIETNAMESE MOBILE TELECOMMUNICATION INDUSTRY
}

\author{
Trinh Kim Hoa ${ }^{1}$, Luu Thi Bich Ngoc ${ }^{2}$ \\ ${ }^{1}$ Bayer Vietnam Ltd, ${ }^{2}$ Open University Malaysia \\ Email: hoatrinhbayer@yahoo.com
}

(Received : 01/08/2014; Revised: 19/09/2014; Accepted: 19/05/2015)

\begin{abstract}
This study was aimed at investigating three factors (service quality, brand image and price perception) and assessed the degree of the impact of each factor on customer satisfaction, especially the relationship between customer satisfaction and customer loyalty in Vietnamese mobile telecom sector where there have been the existence of the fierce competition, mature market and internationally integrated economy, ultimately struggling for market share and survival. The results indicated that each factor (service quality, brand image, price perception) has a positive impact on customer satisfaction at the different level as well as a significantly positive relationship between customer satisfaction and customer loyalty in mobile telecommunication industry in Vietnam. The results of this study are consistent with the findings and evidence in the extant literature. The study provides the important feedback from customers to mobile telecom suppliers. Research findings are expected to be marketing insights for Vietnamese mobile telecom managers so that they can develop the sound marketing strategies in today's competitive and costly market.
\end{abstract}

Keywords: service quality; brand image; price perception; customer satisfaction; customer loyalty; mobile telecommunication industry.

\section{Introduction}

Mobile telecommunication industry has been playing an economically important role in today's increasingly fast - growing society. Therefore, not surprisingly, this has inspired many researchers, marketers as well as management scholars to do many researches in this sector. Since the 1990s, mobile telecommunication service has soon become a dynamic sector of economic development in the industrialized nations. That is not only because of the rapid development of technology but also because of the increasing amount of network operators. In addition, the fiercely high competition among mobile telecom service providers is inevitable in this field.

It has been proved in many empirical studies that as market becomes increasingly competitive and difficult, the companies tend to make many efforts to maintain the market share by focusing on satisfying and retaining the existing customers. Because of the high cost of reaching and attracting new customers, it is extremely important for companies to strategically concentrating on customer retention and customer loyalty. Hence, how to satisfy and make customers increasingly loyal is becoming a strategic goal for any business.

Vietnamese mobile telecommunication market is no longer a market of monopoly. Internationally-integrated economy has had an impact on mobile telecom industry in everfiercely competitive market. According to the Department of Telecommunications (Ministry of Information and Telecommunications), by the end of May 2013, the number of telephone subscribers on the entire network of Vietnam totaled 132.8 million. More particularly, 
mobile subscribers occupied 122.79 million (92.5 percent) and 10 million was for landline subscribers (7.5 percent). With the population of approximately 88 million people, one person uses an average of about 1.5 mobile numbers (Ha, 2013).

In its report "Research and Markets: 2013 Vietnam Telecommunications Services Report", Business Wire (2013) stated that 2011-2012 was a busy and difficult period for the telecommunications sector in Vietnam. The mobile telecommunication industry has left its hot growth stage to dig deeper in the saturated area. There will be no more leapfrogging in revenue streams and the number of subscribers.

Obviously, mobile telecommunication service providers need to fully realize the relevance and significance of the orientedcustomer business strategy as a condition for sustaining the competitive advantages and achieving profitable targets. When a number of subscribers reach a level of saturation, acquiring new customers is not only complicated but also costly from marketing point of view. It is widely believed that the fundamental marketing strategy in the future is to maintain the existing customers by capitalizing upon the customer satisfaction, thus leading to customer loyalty. As a result, the strategic focus of how to investigate the factors influencing on customer satisfaction and customer loyalty is a business and research necessity for management in mobile telecommunication industry.

Vietnamese mobile network suppliers have been struggling with the increasingly fierce competition at not only domestic level but also international level. In addition, there has been the state of the slower growth rate and saturated market. Under these circumstances, a defensive strategy is much more significant than an aggressive one, which expands the size of the overall market by persuading the potential customers (Fornell, 1992). Therefore, it would be time for management of each Vietnamese mobile network supplier to find out the best ways on how to keep, retain and satisfy customers, thereby making them to be more and more loyal to mobile telecom services the operaters provide, and more importantly, for customer profitability. Needless to say, deriving from managerial statement, it is imperative for mobile telecom service providers to investigate the main factors which affect customer satisfaction, thus creating customer loyalty in Vietnamese mobile telecom market.

Many researchers have especially emphasized and revolved around the importance of service quality, brand image and price perception in correlation with customer satisfaction and customer loyalty in service industry (Sureshchandar et al., 2002; Parasuraman et al.,1985; Saravana \& Rao, 2007; Oliver, 1997; Han and Ryu, 2009; Hermann et al., 2007; Davies et al., 2003; Wu, 2011). Besides, the relationship between customer satisfaction and customer loyalty has been evaluated comprehensively in many studies (Szymanski and Henard, 2001; Guiltinan, Paul and Madden, 1997; Fornell, 1992; Oliver, 1999; Lee et al., 2001; Jones and Sasser, 1995; Bei and Chiao, 2001).

While the impacts of some main factors (such as service quality, brand image, price perception) on customer satisfaction as well as the relationship between customer satisfaction and customer loyalty have been intepreted and analysed in the many studies in developed countries mentioned above, there are very few studies on this in Vietnam, especially in mobile telecommunication industry. Therefore, it is determined that this study focuses only on three factors (service quality, brand image and price perception) to evaluate their impacts on customer satisfaction and customer loyalty in Vietnamese mobile telecommunication industry.

\section{Literature review, hypotheses and research model \\ Customer loyalty}

Oliver (1997, p.392) defined customer loyalty as a "deeply held commitment to rebury or repatronize a preferred product or service consistently in the future, thereby causing repetitive same-brand or same brandset purchasing, despite situational influences and marketing efforts having the potential to cause switching behavior". Chu (2009) pointed 
out that loyalty is a positive attitude and behavior related to the level of repurchasing commitment to a brand in the future. Loyal customers are less likely to switch to a competitor solely because of price, and they even make more purchases than non-loyal customers. Loyal customers are considered to be the most important assets of a company. Therefore, not surprisingly, Tseng (2007) said that it is extremely important for companies to keep loyal customers who will contribute longterm benefits to the business organizations.

To enhance the financial growth of a company, thing should be done is to make existing customers increase their purchases (Hayes, 2008). Moreover, organization's financial growth is dependent on a company's competency to retain existing customers at a faster rate than it acquires new ones (Hayes, 2008). Hence, management should understand that the road to growth is to focus on customers - not only attracting new customers but also maintaining existing customers, motivating them to spend more and getting them to recommend products and services to the other people (Keiningham et al., 2008).

According to Aydin and Ozer (2005), customer loyalty has been generally divided into attitudinal loyalty and behavioral loyalty. They stated that attitudinal loyalty describes customer's attitude toward loyalty by measuring customer preference, buying intention, supplier prioritization and recommendation willingness. Meanwhile, behavioral loyalty relates to shares of purchase, purchasing frequency. Wulf et al. (2001) defined the construct of behavioral loyalty as a composite measure based on a consumer's purchasing frequency and amount spent at a retailer compared with the amount spent at other retailers from whom the consumer buys. Morgan and Hunt (1994) found significant relationships between the level of a buyer's relationship commitment and his acquiescence, propensity to leave, and cooperation, all of which can be regarded as behavioral outcomes of relationships.

Conceptualization and measurement of loyalty concept has become more and more complex (Jones and Taylor, 2007). Reichheld
(2003) found that, in service industry, loyalty can be measured by one special indicatorwillingness to recommend. Ball et al. (2004) reviewed the literature related to the determinants of loyalty, not only in the business-to-business but also in business-toconsumer cases. They stated that investigating customer loyalty and its antecedents in the different markets and countries may produce significant variance in the loyalty interpretation. Jacoby and Kyner (1973) emphasized that loyalty has to be: biased, behavioural response, expressed over time, by some decision-making units, with respect to one or more alternative brands out of a set of such brands and a function of psychological processes.

\section{Customer satisfaction and customer loyalty}

The most widely accepted conceptualisation of the customer satisfaction concept is the expectancy disconfirmation theory. This theory was invented by Oliver (1980), who suggested that satisfaction level is a result of the difference between expected and perceived performance. Satisfaction (positive disconfirmation) occurs when product or service is better than expected. Conversely, a performance worse than expected results in dissatisfaction (negative disconfirmation).

Fornell (1992) defined satisfaction as an overall evaluation dependent on the total purchase. Fornell (1992) also found that high customer satisfaction will lead to the increased loyalty for the company and, more importantly, customers will be less likely to make overtures to competitors. Likewise, Jones and Sasser (1995) described that an increase in customer satisfaction brings about a stronger influence on loyalty among customers who are at the high end of the satisfaction scale.

Guiltinan, Paul and Madden (1997) also investigated that satisfied customers tend to be repeated (and even become loyal) customers and are less likely to switch to other service providers. Many scholars have believed that customer satisfaction is one of the best indicators of a company's future profit and competitiveness. The results of customer 
satisfaction include customer loyalty (Bei and Chiao, 2001). Both marketing academics and professionals have aimed to identify the most noticeable determinants of customer loyalty. Researchers have recognized a bond between customer satisfaction and loyalty. In metaanalysis study, Szymanski and Henard (2001) demonstrated 15 positive and significant interconnections between the two constructs. Bearden and Teel (1983) have also indicated a relationship between satisfaction and loyalty. Meanwhile, Jones et al. (1995) found out that this relationship is not a simple linear one and the resulting behaviors may depend on consumer attributions (their belief in the causes of the customer satisfaction and dissatisfaction assessment). Furthermore, some academics pointed out that switching costs, a moderating variable, can substantially impact customer loyalty through customer satisfaction (Fornell, 1992; Oliver, 1999; Lee et al., 2001) and perceived value (Woodruff, 1997; Neal, 1999). Evidently, it is widely recognized that customer satisfaction is a driver of customer loyalty. However, the number of findings in services marketing literatures and empirical studies over the past decade has shown that, in service industry, customer satisfaction and loyalty do not always correlate positively (Silvestro and Cross, 2000; Kamakura, 2002; Pritchard and Silvestro, 2005).

Based on literatures and findings on customer satisfaction and customer loyalty discussed above, the hypothesis is proposed in Vietnamese mobile telecommunication industry:

H4: Customer satisfaction has a positive impact on customer loyalty

Service quality and customer satisfaction

Gronroos (2000, p.46) stated that "a service is a process consisting of a series of more or less intangible activities that normally, but not necessarily always, take place in interactions between the customers and service employees and/or physical resources or goods and/or systems of the service provider, which are provided as solutions to customer problems". This definition showed that service is a process in which interactions between customer and service provider most often exist. Hence, in a service context, relationship between customer and service provider can be utilized as a basis for marketing strategies (Gronroos, 2000).

Service quality is defined as "an overall assessment of services by the customers"(Ganguli \&Roy, 2010, p.405). In service industry, service quality is evaluated by interaction and interconnection between customers and firm employees. This implies that "quality evaluations are made not solely on outcomes of a service, they also involve the evaluations of process of service delivery"(Parasuraman, Zeithaml and Berry, 1988, p.42). It is also stated that service quality is a critical and indispensable factor in persuading customers to use a particular service provider instead of another (Kandampully, 1998). With respect to the relationship between customer satisfaction and service quality, Oliver (1993) first maintained that service quality would be a determinant of customer satisfaction irrespective of whether these constructs were cumulative or transaction-specific. Some researchers have identified the empirical evidences for the viewpoint mentioned above (Anderson \& Sullivan, 1993; Fornell et al 1996; Spreng \& Macky 1996) in which customer satisfaction came as an outcome of service quality.

Although it is proven that other factors such as price and product quality can impact on customer satisfaction, service quality is a antecedent to customer satisfaction (Zeithaml et al., 2006). This finding is in line with the invention of Wilson et al. (2008) and has been supported by the definition of customer satisfaction demonstrated by other researchers. It is evident that, based on past studies of service quality and customer satisfaction, customer satisfaction and service quality themselves are interconnected from their definitions to relationships. Parasuraman et al. (1985) explained that when perceived service quality is high, then it will lead to increase in customer satisfaction. Some other scholars did grasp the idea proposed by Parasuraman(1995) and they significantly recognized that "Customer satisfaction is based upon the level of service quality that is provided by the service providers" (Saravana \& Rao, 2007, p. 
436; Lee et al., 2000, p. 226). Sureshchandar et al. (2002) in their research on relationship of customer satisfaction and service quality, pointed out that these two variables are positively related, confirming that the definitions of both variables are always been connected. They also determined that "service quality is more abstract, since it may be influenced by perceptions of value or by the experiences of others that may not be so good, than customer satisfaction which reflects the customer's feelings about many encounters and experiences with service firm". (Sureshchandar et al., 2002, p. 372).

Therefore, based on literature review mentioned above, the hypothesis is proposed in Vietnamese mobile telecommunication industry:

\section{H1: Service quality has a positive impact on customer satisfaction}

Price perception and customer satisfaction

Zeithal (1988, p.10) has defined the price as "what is given up and sacrificed to obtain a product". Price is an essential determinant of customer satisfaction as it is extrinsic indicator of quality. Jacoby and Olson(1977) distinguished price as objective price and perceived price. They defined objective price as the actual price of a product or service. Meanwhile, perceived price is the price that is encoded by consumer (Zeithaml, 1988). Chang and Wildt(1994) defined the perceived price as consumers' perceptual representation or subjective perception of the objective price of product or service. Varki and Colgate (2001) stated that price perception is created in comparison with the internal reference prices.

Customers tend to choose their service providers based on the perceived price. Because of different needs and wants among individuals, how much consumers are willing to pay for the same service is to vary. Higher price perception might negatively affect purchasing probabilities (Peng and Wang, 2006). Perceived price is also found to be related to price searching (Lichtenstein et al., 1993). The likelihood is that consumers usually are attracted by perceived high-quality services at perceived competitive prices during the searching process.

Oliver (1997) stated that consumers often evaluate the price in relation to service quality, thus generating satisfaction or dissatisfaction. If consumers see price to be fair, they are more likely to enter into transactions with the service providers. Based on previous researches, Cheng et al. (2008) suggested that perceived price can be measured by two constructs: one is rationality of prices, which reflects the way that price is perceived by customers compared with that of competitors; another is value for money, which implies the relative status of the service provider in terms of price. Many researchers have maintained that price perception affects customer satisfaction (Oliver, 1997; Peng and Wang, 2006; Cheng et al., 2008; Kim et al., 2008). Peng and Cheng (2006) believed that customers often switch to another service providers mainly because of some pricing issues such as high price perception, unfair or deceptive pricing policies. In service industry, Singh and Serdeshmurkh (2000) have also pointed out that price significantly influences customer satisfaction. Han and Ryu (2009) identified that price perception impacts considerably on customer satisfaction in restaurant industry. Hermann et al. (2007) found that perceived price has a positive influence on customer satisfaction. Therefore, the hypothesis is proposed in Vietnamese mobile telecommunication industry:

\section{H2: Price perception has a positive impact on customer satisfaction}

Brand image and customer satisfaction

Brand concept has been usually interpreted and analyzed in marketing literatures. Not only is brand building a pivotal driver for marketing physical products, it is but also an important issue for service firms. Keller (1993, p3) defined brand image as "the perceptions about a brand held in consumers' memory". A similar definition to Keller's was suggested by Aaker (1991), whereby brand image is mentioned as "a set of associations, usually organized in some meaningful way" (p. 109). Furthermore, Biel (1992) defined 
brand image as "a cluster of attributes and associations that consumers connect to the brand name" (p. 8).

Gronroos (2000, p.287) stated that "A brand is not first built and then perceived by the customers. Instead, every step in the branding process, every brand message, is separately perceived by customers and together add up to brand image, which is formed in customers' mind". Hence, brand image is an outcome of how a customer makes perceptual relationship with a brand over time. The advancement of a brand relationship with customers is based on a series of brand contacts experienced by customers (Gronroos, 2000). Importantly, service providers need to form a positive brand image in customers' mind, thus conveying brand value to customers and creating a supportive word of mouth among people.

Corporate brand image has been evaluated as an important antecedent of customer satisfaction and loyalty (Wu, 2011). Davies et al. (2003) noted that there has been a positive relationship between corporate brand image and satisfaction. Martineau (1958) said that if consumers advocate image of the store, they will be more likely to develop a certain degree of satisfaction and loyalty. Selnes (1993) also determined the impact of brand image on customer satisfaction. However, Davies and Chun (2002) maintained that brand image had an indirect impact on brand loyalty via customer satisfaction.

Therefore, the hypothesis is proposed in Vietnamese mobile telecommunication industry:

H3: Brand image has a positive impact on customer satisfaction

Based on the literature review and hypotheses mentioned above, research model is proposed as follows:

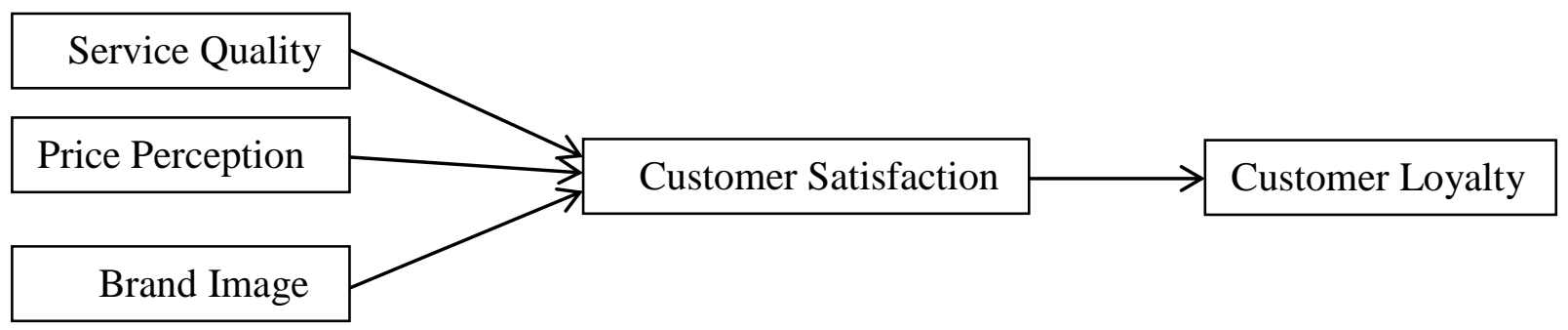

Figure 1. Research model

\section{Research methodology}

Target population

The objective of this study is to determine the degree of the impact of service quality, brand image and price perception on customer satisfaction and customer loyalty in Vietnamese mobile telecommunication sector. Therefore, the customers who are using mobile telecommunication services (such as Viettle, Vinaphone, Mobiphone, Vietnamobile and Gmobile) are target sample population of this research.

\section{Measurement scale}

Scales of this study were based on theories, findings and scales that many researchers used in their empirical studies. Most of scales were borrowed from Godfred et al. (2012), who also adapted the scales from the other researchers: Service quality was measured by 4 items(SQ1, SQ2, SQ3, SQ4) adapted from Gronroos(2000); Price perception was measured by 3 items(PP1, PP2, PP3) adapted from Cheng et al.(2006); Brand image was measured by 4 items (IM1, IM2, IM3, IM4) adapted from Gronroos(2000); Customer satisfaction was measured by 4 items(CS1, CS2, CS3, CS4) adapted from Oliver (1997) and Fornel(1992); Customer loyalty was measured by 5 items (CL1, CL2, CL3, CL4, CL5) adapted from Aydin and Ozer (2005). The author used fivepoint Likert scale from 1-strongly disagree to 5 -strongly agree to investigate the opinions of respondents as a scale measurement.

research

Qualitative research and quantitative 
First of all, preliminary scale was suggested for questionnaires of study. Next, the in-depth interview was conducted with 10 respondents (2 managers of mobile telecommunication companies and 8 customers using mobile telecom services). Participants were required to review the meaning of scales (measurable items) and recommend modifying the scales if necessary in order to remove ambiguities and enhance the clarity of scales . The outcomes, recommendations and feedbacks of in-depth interview had been recorded, thus developing, modifying and qualifying the draft questionnaires (scales) before they were officially launched in main research. The results of qualitative research was presented in the appendix A "Guideline for a qualitative in-depth interview".

Based on the results of the preliminary research, questionnaires were modified again to make sure that the ambiguity of questionnaire has to be removed, thus helping respondents understand questionnaires easily and transparently. When questionnaires were well designed, the main research was conducted. The 450 questionnaires of hard copies were sent out to customers who have been using the mobile telecommunication services. The author received back 406 questionnaires with the percentage of responses of 90\% (406/450). After examining carefully, 18 of the answered questionnaires had the errors and the incomplete responses, thus removing from the list of responses. Ultimately, the valid sample size of this study is 388 .

\section{Data analysis method}

- Data was analyzed by SPSS software, version 16.0, which enables the Exploratory Factor Analysis(EFA), Cronbach's alpha Analysis and Standard Multiple Regression.

- Cronbach's alpha Analysis was used to test reliability of measurement scales.

- Exploratory Factor Analysis (EFA) was employed to explore the interrelationships among variables to identify the number of underlying factors. Principle Component Analysis (PCA) was used as a method to extract the factors in this study, together with Vorimax as a rotation technique.

- Multiple regression was used to test research model and hypotheses.

\section{Data analysis and findings} samples

Descriptive statistics of research

450 questionnaires were administered to customers of mobile telecommunication companies in Ho Chi Minh city. There were 406 responses in which 18 of responses were incomplete. Therefore, a number of valid responses were 388 . Out of 388 responses, $30 \%$ were Viettle, $34 \%$ were Vinaphone, $27 \%$ were Mobilphone, $5 \%$ were Vietnamobile and $4 \%$ were Gmobile. In terms of method of payment for mobile services, the vast majority of customers $(77 \%)$ in this study chose the way of "prepaid", while only $23 \%$ used "paid after" service. About duration of service usage, it is noticeable that the numbers of customers using mobile service for 3-5 years were highest, at $37 \%$, and followed by group of 1-3 years, $19 \%$. Meanwhile, the figures for respondents using mobile services for " $<1$ year" and "5-10 years" were almost similar, $13 \%$ and $12 \%$ respectively. Customers who used mobile services more than 10 years were only about $9 \%$.

From educational point of view, not surprisingly, the figure for respondents who earned Bachelor degree was highest, around $57 \%$. In contrast, the figures for mobile customers who belonged to "below high school diploma", "high school" and "master degree and upper" group were relatively low, at $2 \%, 5 \%$ and $8 \%$ respectively. Customers with Associate degree accounted for $28 \%$. About gender, while the large number of respondents were male $(65 \%)$, the figure for female customers was 35\%. In this survey, markedly, the percentage of mobile customers from 20 to 39 years old was overwhelmingly high, at about $84 \%$, in compared to group less than 9 years old and group more than 40 years old, with $9 \%$ and $7 \%$ respectively. The 
result showed that only half the respondents had income per month from 5 million VND to 10 million VND, with 56\%. However, the proportion of respondents who have high income(more than 15 million VND) was lowest, 9\%. Mobile customers who fell into 510 million group accounted for $21 \%$, compared with $14 \%$ for less than 5 million group.

Reliability test: Cronbach's alpha test

The Cronbach's Alpha test helps to remove the unsuitable scales. If correlation of each specific item with total of the other items in scales is moderately high or higher above 0.3(Burnstein and Nunnally, 1994), the item is probably at least moderately correlated with most of other items and will make a good component of this summated rating rate. If the item-total correlation is negative or too low(less than 0.3), it is required to examine the item for wording problems or conceptual fit.

Table 1. Reliability Test Result

\begin{tabular}{|c|c|c|c|c|}
\hline Description & $\begin{array}{l}\text { Scale Mean if } \\
\text { Item Deleted }\end{array}$ & $\begin{array}{l}\text { Scale Variance if } \\
\text { Item Deleted }\end{array}$ & $\begin{array}{l}\text { Corrected Item- } \\
\text { Total Correlation }\end{array}$ & $\begin{array}{l}\text { Cronbach's Alpha } \\
\text { if Item Deleted }\end{array}$ \\
\hline Service quality & Alpha $=0.773$ & & & \\
\hline SQ1 & 10.7474 & 4.391 & .575 & .720 \\
\hline SQ2 & 10.6701 & 4.403 & .671 & .668 \\
\hline SQ3 & 10.8557 & 4.635 & .587 & .713 \\
\hline SQ4 & 10.6237 & 5.078 & .477 & .767 \\
\hline Brand image & Alpha $=0.781$ & & & \\
\hline IM1 & 10.8557 & 4.821 & .526 & .759 \\
\hline IM2 & 11.0747 & 4.943 & .585 & .729 \\
\hline IM3 & 10.9098 & 4.625 & .631 & .704 \\
\hline IM4 & 10.5902 & 4.594 & .606 & .717 \\
\hline Price perception & Alpha $=0.746$ & & & \\
\hline PP1 & 6.6933 & 2.399 & .623 & .601 \\
\hline PP2 & 6.7216 & 2.408 & .605 & .622 \\
\hline PP3 & 6.4149 & 2.719 & .493 & .750 \\
\hline Customer satisfaction & Alpha $=0.816$ & & & \\
\hline $\mathrm{CS} 1$ & 10.3814 & 4.640 & .599 & .787 \\
\hline $\mathrm{CS} 2$ & 10.3222 & 4.446 & .690 & .742 \\
\hline $\mathrm{CS} 3$ & 10.2448 & 4.713 & .659 & .758 \\
\hline CS4 & 10.2242 & 4.846 & .599 & .785 \\
\hline Customer loyalty & Alpha $=0.843$ & & & \\
\hline CL1 & 13.7887 & 8.229 & .677 & .802 \\
\hline CL2 & 14.0387 & 8.601 & .554 & .838 \\
\hline CL3 & 13.8686 & 8.729 & .657 & .809 \\
\hline CL4 & 13.8376 & 8.312 & .705 & .795 \\
\hline CL5 & 13.8789 & 8.572 & .658 & .808 \\
\hline
\end{tabular}

\section{Service quality}

Service quality is composed of four items. To assess whether the four items that were summed to create the score of service quality formed a reliable scale, Cronbach's alpha was computed. The alpha for four items 
was 0.773 , which indicates that the items form a scale that has reasonable internal consistency reliability. The corrected item-total correlation of each item was above 0.3 , which is suitable to make a scale of service quality.

\section{* Brand image}

Brand image is composed of four items. It was tested whether these items go together (interrelate) well enough to add them for the use as a composite labeled "brand image". The Alpha for four items was 0.781, which indicates that three items are acceptable to make a composite of "brand image". Obviously, the alpha of brand image is higher than alpha of service quality. The corrected item-total correlation of each item was above 0.3 , which is acceptable to make a scale of brand image.

\section{- Price perception}

Price perception is composed of only three items. The author tested whether these three items can go together (interrelate) good enough to add them for the use as a composite labeled "price perception". The Alpha for three items was 0.746. It means that three items can be used to measure the construct of "price perception". The corrected item-total correlation of three items was higher than 0.3, which is suitable to make a reliable scale for measuring "price perception".

\section{* Customer satisfaction}

Customer satisfaction consists of four items. It is necessary to test whether these four items can go together (interrelate) good enough to add them for the use as a composite labeled "customer satisfaction". The Alpha for four items was 0.816 , which indicates that these items form a scale that has a high internal consistency reliability. The corrected item-total correlation of four items was above 0.3 , which is acceptable.

\section{* Customer loyalty}

Customer loyalty is composed of five items. The Alpha for the five items was rather high (0.843). The corrected item-total correlation of five items was above 0.3. All requirements were met. Hence, it is totally acceptable when using this scale for measuring "customer loyalty".

In conclusion, Cronbach's Alpha of five scales was above 0.7 and the corrected itemtotal correlation of all items was higher than 0.3 . It means that all scales fit requirement for reliability test. Therefore, these measurement scales were used to conduct the official research with the aim of testing hypotheses.

Exploratory Factor Analysis (EFA)

\section{EFA for independent variables}

Based on the test of assumption, KMO value was 0.879 at the Barlett's Test Significance of $.000<0.05$. Therefore, it met the conditions require by the EFA method. KMO value of 0.879 indicated sufficient items for each factor. The Barlett was significant, meaning that the variables were correlated highly enough to provide a reasonable basis for factor analysis. By doing EFA (principal component analysis, rotation method: Varimax), it extracted three factors(service quality, price perception and brand image) from 11 items. It was noted that all of three factors had eigenvalues larger than 1.0 (4.672; $1.238 ; 1.131)$, which is a common criteria for a factor to be useful (presented in Table 2).

Table 2. Total variance explained of independent variables

\begin{tabular}{cccccccccc}
\hline Components & \multicolumn{3}{c}{ Initial eigenvalues } & \multicolumn{3}{c}{$\begin{array}{c}\text { Extraction Sums of Squared } \\
\text { Loadings }\end{array}$} & \multicolumn{3}{c}{$\begin{array}{c}\text { Rotation Sums of Squared } \\
\text { Loadings }\end{array}$} \\
& & & \% of & Cumulative & \multicolumn{3}{c}{$\begin{array}{c}\% \text { of } \\
\text { Cumulative }\end{array}$} & \multicolumn{4}{c}{ of } & Cumulative \\
& Total & Variance & $\%$ & Total & Variance & $\%$ & Total & Variance & $\%$ \\
\hline 1 & 4.672 & 42.471 & 42.471 & 4.672 & 42.471 & 42.471 & 2.470 & 22.459 & 22.459 \\
2 & 1.238 & 11.254 & 53.725 & 1.238 & 11.254 & 53.725 & 2.451 & 22.281 & 44.740 \\
3 & 1.131 & 9.375 & 63.100 & 1.131 & 9.375 & 63.100 & 2.020 & 18.360 & 63.100 \\
\hline
\end{tabular}

Extraction Method: Principal Component Analysis. 
The cumulative of three factors accounted for $63.1 \%$. The Rotated Factor Matrix displays the items and factor loadings for rotated factors. Normally, loading larger than 0.4 is acceptable. It is noticeable that 11 items were clearly clustered into three groups of service quality, brand image and price perception defined by high loadings.

Table 3. Rotated component matrix of independent variables

\begin{tabular}{lllll}
\hline & \multicolumn{3}{c}{ Component } & 3 \\
\cline { 2 - 5 } Description & \multicolumn{3}{c}{1} & \\
\hline Brand image & IM3 & .804 & & \\
& IM4 & .759 & & \\
& IM2 & .672 & & \\
& IM1 & .649 & .769 & \\
\hline Service quality & SQ3 & & .767 & .878 \\
& SQ2 & .671 & .819 \\
& SQ4 & & .646 & .540 \\
\hline Price perception & SQ1 & & & \\
& PP2 & & & \\
& PP1 & & & \\
& PP3 & & & \\
&
\end{tabular}

Extraction Method: Principal Component Analysis; Rotation Method: Varimax

* EFA for mediator variable- Customer satisfaction

KMO was 0.793, which indicated sufficient items for each factor. The Barlett's test of Sphericity was significant (.000), which means that the variables are correlated highly enough to provide a reasonable basis for factor analysis. The eigenvalue was larger 1.0 (2.583) and four variables measure one factor of customer satisfaction with 64.57 percent of variance extracted. Loadings for four items were high enough:

Table 4. Component matrix of mediator variable-customer satisfaction

\begin{tabular}{ll}
\hline Description & Component \\
\cline { 2 - 2 } & 1 \\
\hline CS2: I am satisfied with the professional competence of supplier X & .842 \\
CS3: I am satisfied with the performance of the frontline employees of supplier X & .822 \\
CS4: I am comfortable about the relationship with supplier X & .775 \\
CS1: I am satisfied with the overall service quality offered by supplier X & .773 \\
\hline
\end{tabular}

Extraction Method: Principal Component Analysis; 1 component extracted.

EFA for dependent variable-customer loyalty

The result of EFA showed that there was only one factor underlying this construct in which the five items measure customer loyalty(accounted for $61.83 \%$ of variance extracted) with eigenvalue larger than 1.0 (3.092) and KMO value of 0.849 at the significance of 0.000 . Loadings for five items were enough high: 
Table 5. Component matrix of dependent variable-customer loyalty

\begin{tabular}{ll}
\hline Description & Component \\
\cline { 2 - 2 } & 1 \\
\hline CL4: I am willing to say positive things about supplier X to other people & .832 \\
CL1: I intend to continue using mobile services from this operator for a long time & .805 \\
CL5: I will encourage friends and relatives to use the services offered by supplier X & .794 \\
CL3: Even if another operator' price is lower, I will go on using supplier X & .794 \\
CL2: If I want an additional telecom service, I am willing to continue selecting supplier X & .700 \\
\hline
\end{tabular}

Extraction Method: Principal Component Analysis; 1 component extracted.

\section{Hypotheses testing} regression

Testing the assumption of multiple

When running multiple regression, multicollinearity must be put much attention to as this problem can lead to inaccurate results. Multicollinearity problem occurs in case there are high inter-correlations among the independent variables. Pearson Correlation below (presented in Table 6) indicates a low correlation (lower than 0.8) among predictor variables. When the assumption of Standard Multiple regression was met, a further analysis on the regression results was proceeded to test the research hypotheses.

Table 6. Pearson correlation

\begin{tabular}{lllll}
\hline & & Service quality & Brand image & Price perception \\
\hline Service quality & Pearson Correlation & 1 & $.588^{* *}$ & $.492^{* *}$ \\
& Sig. (2-tailed) & & .000 & .000 \\
Brand image & Pearson Correlation & $.588^{* *}$ & 1 & $.475^{* *}$ \\
& Sig. (2-tailed) & .000 & & .000 \\
Price perception & Pearson Correlation & $.492^{* *}$ & $.475^{* *}$ & 1 \\
& Sig. (2-tailed) & .000 & .000 & \\
\hline
\end{tabular}

** Correlation is significant at the 0.01 level (2-tailed)

Testing hypotheses on the impacts of section, the author decided the final model for factors (service quality, brand image, price the study with three factors as independent perception) on customer satisfaction:

According to the analysis in previous variables: service quality, brand image, price perception.

Table 7. Model summary of testing hypotheses on the impacts of factors (service quality, brand image, price perception) on customer satisfaction

\begin{tabular}{lllll}
\hline Model & $\mathrm{R}$ & R Square & Adjusted R Square & Std. Error of the Estimate \\
\hline 1 & $.733^{\mathrm{a}}$ & .538 & .534 & 1.90683 \\
\hline
\end{tabular}

a. Predictors: (Constant), Price perception, Brand image, Service quality

The Model summary table showed that the multiple correlation coefficient $(\mathrm{R})$, using all the predictor simultaneously, was
0.733. The Adjusted R Square was 0.534, which indicates that $53.4 \%$ of variance in customer satisfaction can be predicted from 
the independent variables combined (price The model for this study is strongly suitable. perception, brand image, service quality).

Table 8. ANOVA ${ }^{b}$ Result of Testing hypotheses on the impacts of factors (service quality, brand image, price perception) on customer satisfaction

\begin{tabular}{lllllll}
\hline Model & & Sum of Squares & df & Mean Square & F & Sig. \\
\hline 1 & Regression & 1625.275 & 3 & 541.758 & 148.999 & $.000^{\mathrm{a}}$ \\
& Residual & 1396.217 & 384 & 3.636 & & \\
& Total & 3021.492 & 387 & & & \\
\hline
\end{tabular}

a. Predictors: (Constant), Price perception, Brand image, Service quality

b. Dependent Variable: Customer satisfaction`

The ANOVA table shows that $\mathrm{F}=148.99$ and is significant. This indicates that the combination of the predictors significantly (.000) predicts customer satisfaction.

Table 9. Coefficients ${ }^{\mathrm{a}}$ Result of Testing hypotheses on the impacts of factors (service quality, brand image, price perception) on customer satisfaction

a. Dependent Variable: Customer

satisfaction `

According to the Coefficients matrix, three factors (service quality, brand image and price perception) were positively related to customer satisfaction because all Standardized Coefficients Beta are positive. Especially, sig. is $.000(\mathrm{p}<0.05)$, indicating that Service quality, brand image and price perception were significantly contributing to the equation for predicting customer satisfaction. It means that all of three factors examined in this study are the meaningful factors to customer satisfaction in mobile telecommunication industry. In the other word, if we increase the level of service quality, price perception and brand image, customer satisfaction will improve. Among three factors that influence on customer satisfaction, Coefficients Table shows that Brand image (Coefficient Beta $=0.345$ ) is the factor that has the highest positive impact on customer satisfaction from the viewpoint of customers in Vietnamese mobile telecommunication sector. The factor that has the second high influence on customer satisfaction is Service quality (Coefficient Beta=0.307). It implies that, in mobile telecom sector, if we enhance the level of service quality, customer satisfaction will improve. The third factor, Price perception, is believed to be a factor that has the lowest positive impact on customer satisfaction in this study with Coefficient Beta of 0.232. It is also noted that, in Vietnamese mobile telecommunication industry, if price perception increases from point of view of customers, customer satisfaction will develop.

Testing hypothesis on the impact of customer satisfaction on customer loyalty 
Table 10. Model Summary of Testing hypothesis on the impact of customer satisfaction on customer loyalty

\begin{tabular}{lllll}
\hline Model & $\mathrm{R}$ & $\mathrm{R}$ Square & Adjusted R Square & Std. Error of the Estimate \\
\hline 1 & $.692^{\mathrm{a}}$ & .478 & .477 & 2.58337 \\
\hline
\end{tabular}

a. Predictors: (Constant), Customer satisfaction

The Model Summary table showed the results of $\mathrm{R}=0.692$ and Adjusted $\mathrm{R}$ Square $=0.477$, which represented that the impact of predictor variable (Customer satisfaction) on dependent variable (Customer loyalty) was rather strong and the model could explain $47,7 \%$ of variance in Customer loyalty in Vietnamese mobile telecommunication industry.

Table 11. ANOVA ${ }^{b}$ Results of Testing hypothesis on the impact of customer satisfaction on customer loyalty

\begin{tabular}{lllllll}
\hline \multicolumn{1}{c}{ Model } & & Sum of Squares & df & Mean Square & F & Sig. \\
\hline 1 & Regression & 2362.546 & 1 & 2362.546 & 354.004 & $.000^{\mathrm{a}}$ \\
& Residual & 2576.081 & 386 & 6.674 & & \\
& Total & 4938.626 & 387 & & & \\
\hline
\end{tabular}

a. Predictors: (Constant), Customer satisfaction`

b. Dependent Variable: Customer loyalty

The ANOVA table shows that satisfaction significantly (.000) predicts $\mathrm{F}=354.004$ and is significant. This indicates dependent variable of customer loyalty.

that the predictor variable customer

Table 12. Coefficients ${ }^{\mathrm{a}}$ Result of Testing hypothesis on the impact of customer satisfaction on customer loyalty

\begin{tabular}{|c|c|c|c|c|c|c|c|c|}
\hline \multirow[b]{2}{*}{ Model } & & \multicolumn{2}{|c|}{$\begin{array}{l}\text { Unstandardized } \\
\text { Coefficients }\end{array}$} & \multirow{2}{*}{$\begin{array}{l}\text { Standardized } \\
\text { Coefficients } \\
\text { Beta }\end{array}$} & \multirow[b]{2}{*}{$\mathrm{T}$} & \multirow[b]{2}{*}{ Sig. } & \multicolumn{2}{|c|}{ Collinearity Statistics } \\
\hline & & $\mathrm{B}$ & Std. Error & & & & Tolerance & VIF \\
\hline 1 & (Constant) & 5.217 & .658 & & 7.927 & .000 & & \\
\hline & Customer satisfaction` & .884 & .047 & 692 & 18.815 & .000 & 1.000 & 1.000 \\
\hline
\end{tabular}

a. Dependent Variable: Customer loyalty

The standardized Coefficient Beta value of customer satisfaction provided in Table 4.13 was 0.692 at the Sig. value of 0.000 , indicating that Customer Satisfaction has a positive impact on customer satisfaction in Vietnamese mobile telecom sector.
Summary of hypotheses testing results

The results of hypotheses testing were presented in Table 4.14. Three Hypotheses H1, H2, H3 were supported while Hypothesis H4 was strongly supported. 
Table 13. Results of hypotheses testing

\begin{tabular}{|l|l|l|l|l|}
\hline No. & Hypotheses & $\begin{array}{l}\text { Standardized } \\
\text { Coefficient } \\
\text { (Beta) }\end{array}$ & Sig.(p-value) & Tested Results \\
\hline H1 & $\begin{array}{l}\text { Service quality has a positive impact on } \\
\text { customer satifaction }\end{array}$ & $\mathbf{0 . 3 0 7}$ & 0.000 & Supported \\
\hline H2 & $\begin{array}{l}\text { Price perception has a positive impact on } \\
\text { customer satisfaction }\end{array}$ & $\mathbf{0 . 2 3 2}$ & 0.000 & Supported \\
\hline H3 & $\begin{array}{l}\text { Brand image has a positive impact on } \\
\text { customer satisfaction }\end{array}$ & $\mathbf{0 . 3 4 5}$ & 0.000 & Supported \\
\hline H4 & $\begin{array}{l}\text { Customer satisfaction has a positive impact on } \\
\text { customer loyalty }\end{array}$ & $\mathbf{0 . 6 9 2}$ & 0.000 & $\begin{array}{l}\text { Strongly } \\
\text { Supported }\end{array}$ \\
\hline
\end{tabular}

\section{Conclusions, implications and}

\section{limitations}

Conclusions

The critical aim of this study is to investigate the determinants of customer satisfaction that has influence on customer loyalty in Vietnamese mobile telecommunication industry. In this study, three factors affecting customer satisfaction are suggested: service quality, brand image and price perception, and then this research defines the level and the important impact of customer satisfaction on customer loyalty. After collecting and analyzing the data, some important results are found.

The result of this study demonstrates a positive correlation between three factors (service quality, brand image and price perception) and customer satisfaction in Vietnamese mobile telecommunication industry. It means that if each of these three factors is improved, customer satisfaction will be improved. Each factor makes the different level of impact on customer satisfaction. More specifically, among three factors, brand image is the most important factor that has a strongly positive effect on customer satisfaction (Coefficient Beta=0.345). It implies that, in Vietnamese mobile telecom sector, if mobile telecom companies know how to develop the brand image in the mind of customer, it will lead to an increase in customer satisfaction. Service quality has a second strong effect on customer satisfaction in mobile telecom context (Coefficient Beta=0,307). It indicates that the better the service quality, the higher level the customer satisfaction comes to in mobile telecommunication industry. Meanwhile, price perception has a lowest positive impact on customer satisfaction in compared with two other factors (Coefficient Beta=0.232). However, researchers also have to consider this factor thanks to its significant contribution.

What's more, it is evident that customer satisfaction has a positive effect on customer loyalty with the most significant and highest level of influence (Coefficient Beta=0.692) in Vietnamese mobile telecommunication industry. Therefore, it is extremely important to enhance customer satisfaction if telecommunication companies want to increase customer loyalty.

\section{Managerial implications}

First of all, from customer's perspective, brand image is the most important indicator in comparison to other factors (service quality and price perception) in creating customer satisfaction. Hence, it is extremely essential for managers to work out the marketing strategies on how to develop the image of mobile brand. In today's increasingly competitive mobile telecommunication market, marketing decisions related to development of brand image have to be paid much attention to, thus making mobile customers to be increasingly satisfied. Clearly, in mobile telecommunication industry, how to build up the brand image has been becoming a strategic focus in marketing management. Secondly, service quality also has a significantly positive effect on customer satisfaction as a second important factor. From management point of view, evidently, how to manage and improve the quality of mobile telecommunication services has been a strategic 
role for marketers who want to enhance the customer satisfaction on the purpose of making more profit for mobile telecom service providers. Thirdly, although price perception is proved to be a third strong factor influencing on customer satisfaction in mobile telecom industry, management of mobile service providers should think more of its significant contribution to improvement of customer satisfaction. As a manager of mobile telecom company, he or she has to think strategically about how customer perceives the price. In addition, most importantly, the result of this study shows that customer satisfaction is strongly positively related to customer loyalty in mobile telecom industry. This has also been significantly supported by many findings in marketing literature. As far as marketing management is concerned, it is pivotal for mobile telecommunication managers to focus on customer satisfaction and customer loyalty when they plan and revise the marketing strategies. Customer satisfaction is a strategic focus in creating customer loyalty which can help mobile telecom service providers achieve the long-term financial goals.

direction

Limitations and further research

It is undeniable that Structural Equation Modeling (SEM) is more applicable and practical in current research problems because of some of its capabilities such as having more flexible assumptions, measurement error reduction, testing total model rather than individual coefficients in compared with Multiple Regression which performed analysis separately. However, this study used the method of Multiple Regression to test research model and hypotheses; and this should be mentioned as a research limitation. In future research, SEM should be applied as a popular data-analytic technique thanks to its practical advantages.

In addition, Ho Chi Minh city which is chosen to conduct this study is one of the biggest cities in Vietnam, and it may not represent for all customers in Vietnam. If research had conducted in other places instead of only Ho Chi Minh city, the samples might have been more representative. What's more, method of collecting samples in this study is non-probability sampling, especially convenience sampling. In further research, method of probability sampling can be used to improve the representative of sample. This study only investigates three factors (service quality, brand image and price perception) having impact on customer satisfaction and customer loyalty in mobile telecommunication industry, and it will be far more comprehensive if other factors is included in future research.

\section{REFERENCES}

Aydin, S. and Özer, G. (2005). The analysis of antecedents of customer loyalty in the Turkish mobile telecommunication market. European Journal of Marketing, 39(8), 910925.

Anderson, E.W., Fornell, C., Lehmann, D.R. (1994).Customer satisfaction, market share and profitability: Findings from Sweden. Journal of Marketing, 58(3), 53-66.

Aaker, D. A. (1991). Managing brand equity: Capitalizing on the value of a brand name. New York: The Free Press.

Biel, A. L. (1992). How brand image drives brand equity. Journal of Advertising Research, 32(6). 
Bei, L.T. and Chiao, Y.C. (2001). An integrated model for the effects of perceived product, perceived service quality, and perceived price fairness on consumer satisfaction and loyalty. Journal of Consumer Research, 14, 125-140.

Business Wire (2013, February 6). Research and markets: 2013 Vietnam telecommunications services report. Retrieved from http://www.businesswire.com/news/home/ 20130206006115/en/Research-Markets-2013-Vietnam-Telecommunications-ServicesReport\#.U0oqZqxRrBY

Business Monitor International. (2014, January 15). Vietnam telecommunications report Q1 2014. Retrieved from http://www.marketresearch.com/Business-MonitorInternational-v304/Vietnam-Telecommunications-Q1-7979795/

Bollen, K. A. (1989). Structural equations with latent variables. New York: John Wiley \& Sons, Inc.

Ball, D., Coelho, P.S., \& Machas, A. (2004). The role of communication and trust in explaining customer loyalty: An extension to the ECSI model. European Journal of Marketing, 38(9/10), 1272-1293.

Burnstein and Nunnally (1994). Psychometric theory ( $3^{\text {rd }}$ ed.). New York: McGrow Hill.

Cheng, T. C. E.; Lai, L. C. F. and Yeung, A. C. L. (2008).The driving forces of customer loyalty: A study of Internet service providers in Hong Kong. International Journal of E-Business Research, 4(4), 26-42.

Chu, Kuo-Ming. (2009). The construction model of customer trust, perceived value and customer loyalty. Journal of American Academy of Business, 14(2), 98-103.

Davies, G., Chun, R., Da-Silva, R. \& Roper, S. (2003). Corporate reputation and competitiveness. London: Routledge.

Davies, G. \& Chun, R. (2002). Gaps between the internal and external perceptions of the corporate brand. Corporate Reputation Review, 5, 144-158.

Fornell, C., Johnson, M.D., Anderson, E.W., Cha, J. and Bryant, B.E. (1996), The American customer satisfaction index: Nature, purpose and findings. Journal of Business Research, 60(4), 7-18

Ganguli, S \& Roy, S.K.(2010). Service quality dimensions in hybrid service. Managing Service Quality, 20(5), 404-424.

Godfred et al. (2012). Relationship marketing tactics and customer loyalty : A case of the mobile telecommunication industry in Ghana. Asian Journal of Business Management, 5(1), 77-92.

Guiltinan, J. P., Paul, G. W., \& Madden, T. J. (1997). Marketing management: Strategies and programs( 6th ed.). New York: McGraw-Hill.

Gronroos, C. (2000). Service management and marketing: A customer relationship management approach ( $2^{\text {nd }}$ ed.). USA: John Wiley \& Sons, Ltd.

Ha Thu.(2013, October 31). Mobile telecommunications market: Towards sustainable development. Retrieved from http://vccinews.com/news_detail.asp? news_id=27318 
Han, H and Ryu, K.(2009). The role of physical environment, price perception and customer satisfaction in determining customer loyalty in restaurant industry. Journal of Hospitality and Tourism Research, 33(4), 487-510

Hair, Joseph F., Jr. et al. (2006). Multivariate data analysis( 6th ed.). New York: Prentice-Hall.

Hayes, B. E. (2008). The true test of loyalty. Quality Progress, 41(6), 20-26.

Hermann, A., Xia, L., Monroe, K.B., Huber, F. (2007). Influence of price fairness on customer satisfaction: An empirical text in the context of automobile purchases. Journal of Brand and Product Management, 16(1), 49-58.

ICTnews. (2013, September 3). 20-year pathway of Vietnam's mobile phones, where is the lever? Retrieved from http://www.viettel.com.vn/61-83-2-2254-20-year-pathway-ofVietnam\%E2\%80\%99s-mobile-phones-where-is-the-lever.html.

Jacoby, J., Olson, J.C. (1977). Customer response to price: An attitudinal, information processing perspective . American Marketing Association, 73-86.

Jones, T. and Taylor, S.F(2007). Conceptual domain of service loyalty: How many dimentions ?. Journal of Service Marketing, 21(1), 36-51

Jacoby, J. \& Kyner, D.B. (1973). Brand loyalty vs. repeat purchasing behaviours. Journal of Marketing Research, 10, 1-19.

Jones, T. \& Sasser, W. (1995). Why satisfied customers defect. Harvard Business Review, 73(6), 88-99

Kamakura, W. A., and Mittal, V. (2002). Assessing the service-profit chain. Marketing Science, 21(3), 294-317.

Kim, C. S., Zhao, W. H. and Yang, K. H. (2008). An empirical study on the integrated framework of e-CRM in online shopping: Evaluating the relationships among perceived value, satisfaction, and trust based on customers' perspectives. Journal of Electronic Commerce in Organizations, 6(3), 1-19.

Keller, K. (1993). Conceptualizing, measuring, managing customer-based brand equity. $J$ Mark, 57(1), 1-22.

Kandampully, J. (1998). Service quality to service loyalty: A relationship which goes beyond customer services. Total Quality Management, 9(6), 441-443.

Keiningham, T. L., Aksoy, L., Cooil, B., and Andreassen, T. W. (2008). Linking customer loyalty to growth. MITSloan Management Review, 49(4), 50-57.

Lee, J., Lee, J., and Feick, L. (2001). The impact of switching costs on the customer satisfaction-loyalty link: Mobile phone service in France. Journal of Services Marketing, 15, 35-48.

Lichtenstein, D. R., Ridgway, N. M. and Netemeyer, R.G.(1993). Price perceptions and consumer shopping behaviour: A field study. Journal of Marketing Research, 30(2), 234-245. 
Morgan, RM., and Hunt, S.D., 1994. The commitment-trust theory of relationship marketing. Journal of Marketing. 58 (July), 1994.

Martineau, P. (1958). The personality of retail store. Harvard Business Review, 36(1), 47-55.

Neal,W.D. (1999). Satisfaction is nice, but value drives loyalty. Marketing Research, 21-23.

Oliver, R. L. (1997). Satisfaction: A behavioral perspective on the consumer. New York: McGraw Hill.

Oliver, R. L. (1999). When consumer loyalty? Journal of Marketing, 33-44.

Oliver, R. (1980). Theoretical bases of consumer satisfaction research: review, critique, and future direction. American Marketing Association, 206-210.

Ogba, I. E. \& Tan, Z. (2009). Exploring the impact of brand image on customer loyalty and commitment in China. Journal of Technology Management in China, 4(2), 132-144.

Parasuraman, A., Zeithaml, V.A.and Berry, L.L. (1988). SERVQUAL: A multiple-item scale for measuring consumer perceptions of service quality, Journal of Retailing, $64,12-40$

Peng, Leong Yow \& Wang, Qing (2006). Impact of relationship marketing tactics(RMTs) on switchers and stayers in a competitive service industry. Journal of Marketing Management, 22, 25-59.

Pritchard, M.P., Havitz, M.E. and Howard, D.R.(1999). Analyzing the commitment-loyalty link in service contexts. Journal of the Academy of Marketing Science, 27(3), 333-348.

Reichheld, F.F.(2003). The number one you need to grow. Harvard Business Review, 81(12), 46-54.

Szymanski, D.M. and Henard, D.D. (2001). Customer satisfaction: A meta-analysis of the empirical evidence. Journal of the Academy of Marketing Science, 29(1), 16-35.

Silvestro, R. and Cross, S. (2000). Applying the service profit chain in a retail environment. International Journal of Service Industry Management, 11(3), 244.

Spreng, R.A., Mackenzie, S.B. and Olshavsky, R.W. (1996). A re-examination of the determinant of customer satisfaction. Journal of Marketing, 60(3), 15-32

Sureshchandar G.S., Rajendran C, \& Anantharaman R.N. (2002). The relationship between service quality and customer satisfaction - a factor specific approach. Journal of Services Marketing, 16(4), 363 - 379.

Singh, J. and Sherdesmurk, D. (2000). Agency and trust mechanisms in customer satisfaction and loyalty judgements. Journal of Academy of Marketing Science, 28(1), 150-167.

Selnes, F. (1993). An examination of the effect of product performance on brand reputation, satisfaction and loyalty. European Journal of Marketing, 27(9), 19-35.

Serkan Aydin, Gökhan Özer, (2005). The analysis of antecedents of customer loyalty in the Turkish mobile telecommunication market. European Journal of Marketing, 39, 910 -925 . 
Tseng, Yi Ming (2007). The impacts of relationship marketing tactics on relationship quality in service industry. The Business Review, 7 (2), 310-314.

Tabchnick, B.G. \& Fidell, L.S.(1991).Using multivariate statistics(3 ${ }^{\text {rd }}$ ed.). New York: HarperCollin.

Varki, S., Colgate M. (2001). The role of price perception in an integrated model of behavioural intentions. Journal of Service Research, 3(3), 232-240

Wulf, K. D., Odekerken-schroder, G. and Iacobucci, D. (2001). Investments in consume relationships: A cross-country and cross-industry exploration. Journal of Marketing, 65(4), 33-50

Woodruff, R.B. (1997). Customer value: The next source of competitive advantage. Journal of the Academy of Marketing Science, 25, 139-153

Wilson A., Zeithaml V.A., Bitner M.J., Gremler D.D. (2008) .Services marketing. NY: McGraw-Hill.

Wu, C. C. (2011). The impact of hospital brand image on service quality, patient satisfaction and loyalty. African Journal of Business Management, 5(12), 4873-4882.

Zeithaml V. A., Bitner M. J., Gremler D. D. (2006). Services marketing( 4 edition). NY: McGraw-Hill.

Zeithaml, V.A. (1988). Consumer perception of price, quality and value: A means-end model and synthesis of evidence. Journal of Marketing, 52(3), 2-22. 